\title{
Partnership as an Alternative Model for Empowering Fishers in the Processed Food Industry Made from Marine Fish
}

\author{
Allam ${ }^{4}$, Kornelius Benuf ${ }^{5}$ \\ ${ }^{1}$ Faculty of Law, Universitas Diponegoro, Indonesia \\ sitimalikhatun@live.undip.ac.id \\ ${ }^{2}$ Faculty of Law, Universitas Diponegoro, Indonesia \\ suhartoo@gmail.com \\ ${ }^{3}$ Faculty of Law, Universitas Diponegoro, Indonesia \\ saraswatiretno@yahoo.com \\ ${ }^{4}$ Faculty of Law, Universitas Diponegoro, Indonesia \\ haidarf60@gmail.com \\ ${ }^{5}$ Faculty of Law, Universitas Diponegoro, Indonesia \\ korneliusbenuf@gmail.com
}

Siti Malikhatun Badriyah ${ }^{1}$, R. Suharto ${ }^{2}$, Retno Saraswati ${ }^{3}$, Muhammad Haidar Fakhri

\section{Abstrak}

Introduction to the Problem: This study discusses cooperation between various parties that are mutually beneficial, both the government, large business actors, and small business actors, in this case, fishermen.

Purpose/Objective of the Study: This research aims to maximize the management of fisheries potential in Indonesia and provide alternatives to fishermen out of the problems they face.

Design/Methodology/Approach: This study uses a mixed-method, which combines quantitative and qualitative research.

Findings: The results showed that by looking at the background as well as the potential and weaknesses of the fishing community, the business partnership model could be an alternative to empowering the fishing community in developing the processed food industry made from marine fish. The legal relationship of the parties in this business partnership is based on the partnership agreement.

Paper Type: Research Article

Keywords: Community Empowerment; Fisherman; Industry; Processed Food; Business Partnership

\section{Introduction}

Food processing with marine fish as raw materials has always been a hot topic of conversation in people's lives. It is in line with the increasing public awareness of balanced nutrition. Sea fish is a high protein food needed for human health. The human right to fair and healthy food is protected by law. In the use of processed food, society, in this case, the consumer, must get quality food, which is excellent and safe (Badriyah, Mahmudah, \& Soemarmi, 2019). 


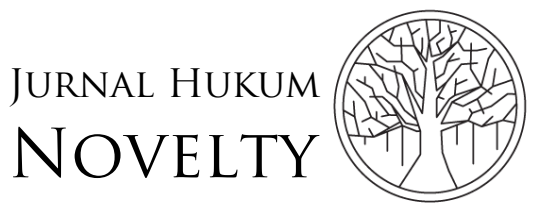

Volume 12, Issue 02, 2021, pp. 225-236

Moreover, food is closely related to people's lives, from religion and belief, law, health, defense, security, politics, economy, society, and culture. The extent of the relationship between food and various life fields has also often sparked debate about food security theories and policies. It is an essential topic in the broader field of economic development and development studies (Burchi \& De Muro, 2016).

Food security and diversity are currently fascinating factors because, in addition to being the community's basic needs, the culinary business is also growing due to the development of community needs in the world of tourism. Culinary tourism is increasing and attracting both domestic and foreign tourists (Satria, 2015). Food includes both processed and non-processed foods. This research focuses on processed food with marine fish as raw materials that empower fishing communities. In various countries in the world, this food issue has become a crucial issue that is always being discussed Asha Kaur (Kaur et al., 2019). It was noted that "Healthrelated claims (HRCs) are found in a food package of the nutritional quality of food (health claims). The European Union (EU) states that Human Resources (HR) must be regulated only to produce and consume foods that meet a specific nutritional profile (NP). "The introduction of quality food issues should be a cultural pattern from an early age to be a significant factor to do," as stated by Ingrid Marie Hovdenak (Hovdenak et al., 2019), Mariel Marcano-Olivie (Marcano-Olivier et al., 2019), Namrata Sanjeevi (Sanjeevi et al., 2019), Shannon M. Robson (Robson et al., 2019). In Indonesia, the food problem is also a serious concern of the government.

Food is anything that comes from biological sources of the agricultural, plantation, forestry, fishery, animal husbandry, water, and water products, whether processed or unprocessed which is designated as food or beverage for human consumption, including food additives, food raw materials, and other materials used in the process of preparing, processing, and making food or beverages (Article 1 number 1 of Law Number 18 of 2012 concerning food (Food Law). Food Production is an activity or process of producing, preparing, processing, making, preserving, packaging, repackaging, and changing the form of Food (Article 1 Number 6 of the Food Law). Processed Food is food or beverage processed by a particular method or method with or without additional ingredients (Article 1 Number 19 of the Food Law). Sea fish is one of the food raw materials that is widely used by the community.

Indonesia has great potential to become a fishery-based food industry because it is supported by its main advantages of available raw materials and downstream, prioritizing sustainability. For this reason, the synergy between ministries and institutions and the empowerment of fishers is needed to support increased added value and a continuous supply of raw materials. The fishing industry is always experiencing developments (Malau, 2014). According to Saleh Husin, even the fishery-based food industry is included in the National Industrial Development Master Plan (RIPIN) priority industry to accelerate future development. This industry's potential is considered large, considering that Indonesia is one of the 
maritime countries with the longest coastline, 99,093 kilometers and an ocean area reaching 80 percent of the total area. So far, more raw fish is exported. It indicates that the opportunity for drowning is wide open.

According to the Ministry of Industry's records, the number of fish canning industries in 2015 reached 41 companies and absorbed an investment of Rp 1.91 trillion. The capacity is 630 thousand tons, but the production is 315 thousand tons. Thus the utilization is only 50 percent. Judging from the export value, the fish processing industry must be encouraged. Under current conditions, processed fish exports are 93.9 thousand tons and a value of $\mathrm{Rp} 342.7$ million tons or around $\mathrm{Rp} 4.5$ trillion. This value will get more significant if the industry is developed. This development will boost labor absorption. The development of the food industry is by the policy for developing a fishery-based food industry, which is divided into phase I (2015-2019) in the form of various fish processing and industrial waste processing development. Phase II (2020-2024) is omega-3 oil production and food products based on fish processing industry waste. For stage III (2025-2035), the fish processing industry has become part of the functional food and supplement industry (Kementerian Perindustrian Indonesia, 2016).

Anglers have an essential role in providing food made from marine fish. The processing of food made from marine fish is carried out by large and small business actors, including Micro, Small, and Medium Enterprises (MSMEs). The central role of anglers in the supply of processed food raw materials is very decisive, especially in Indonesia, which has a relatively large potential for marine binding capacity. This urgent role of fishers is often not in line with the welfare of fishers. Often fishers are described as groups of people who live in slum coastal areas and have insufficient income (Nur, 2021). Various factors cause this condition, including the catch of fishermen's fish, which is directly sold to intermediaries whose value is too low. Therefore, efforts to increase the value of fish by turning it into processed food are urgently needed. However, fishermen have certain obstacles in processing fish themselves as raw material for processed food, including capital, food processing skills, marketing, etc. Therefore, it is necessary to cooperate between various parties that mutually benefit for the government, big business actors and small business actors, in this case, fishers.

Empowerment of the community, especially small entrepreneurs, including the empowerment of the processed food industry made from marine fish to improve the economy requires mutually beneficial cooperation, known as a business partnership. Partnerships between large businesses and small businesses can help small businesses to overcome their weaknesses, among others, through the capital, marketing and technology. These weaknesses also occur in small businesses in the management of processed food made from marine fish. Research on efforts to improve the fisheries industry was conducted by Siti Malikhatun Badriyah (Badriyah, Mahmudah, Soemarmi, et al., 2019) in previous research. Previously there was also 
research on efforts to fulfill the capital to procure boats for small fishers by Siti Malikhatun Badriyah (Badriyah, Mahmudah, \& Soemarmi, 2019). As for research on the empowerment of coastal communities with a partnership, the strategy has been conducted by Siti Mahampang (Mahmudah et al., 2019) in previous research. These studies show that coastal communities have great potential for empowerment in various business activities to improve community welfare; in this case, the fishermen's family and the fishing industry's development. But on the other hand, there are various obstacles in exploring the existing potential, both natural and human resource potential. Therefore, research on fishermen communities' empowerment model in the processed food industry made from marine fish is very urgent to do. In order to answer the research problems, a mixed-method is used, which combines quantitative and qualitative research. In this case, the legal pluralism approach is used, which integrates the normative (state law), sociological (living law), and philosophical (religion, moral, and ethic) approaches.

\section{Methodology}

This study uses a mixed-method, which combines quantitative and qualitative research. The research approach used is the triangular concept of legal pluralism (Menski, 2006), which integrates the 1) normative (state law) approach by looking at written legal regulations relating to the empowerment of fishing communities in the processed food industry made from marine fish 2) sociological (living law), namely revealing and analyzing the empowerment practices of fishing communities in the processed food industry made from marine fish and 3) philosophical (religion, moral, ethic) by studying and analyzing the values, principles that exist in the community, namely small fishermen on the coast. Furthermore, it will provide an alternative model for empowering fishing communities in the processed food industry with marine fish as raw material.

The research location chosen is in the Coastal Zone, considering that in the coastal area, most of the population has a livelihood as fishermen and the Ministry of Fisheries and Marine Affairs and the Ministry of Industry and Trade. Primary data analysis used Strauss and J. Corbin types (Strauss et al., 1990) that analyzes the data since the researcher was in the field. Secondary data is analyzed using deductive logic, especially during the initial analysis (theories). However, it is possible to carry out an analysis using inductive logic on the empowerment of fishing communities in the processed food industry made from marine fish. The data validity used the triangulation technique (Denzin \& Lincoln. Y. S., 1994), source and triangulation methods (Diantha, 2017). The data's validity was also tested through the peer group debriefing technique, a group discussion to discuss research problems by people with similar expertise or peers. 


\section{Results and Discussion}

\section{Efforts to Empower Fishermen in the Development of Processed Food Industry} Made from Sea Fish Raw

The development of capture fisheries production in Indonesia can be seen in the following table.

Table 1. Capture Fisheries Production in Indonesia (in Tons)

\begin{tabular}{lccccc}
\hline Type & \multicolumn{5}{c}{ Year } \\
\cline { 2 - 6 } & $\mathbf{2 0 1 4}$ & $\mathbf{2 0 1 5}$ & $\mathbf{2 0 1 6}$ & $\mathbf{2 0 1 7}$ & $\mathbf{2 0 1 8}$ \\
\hline Marine & $6.037 .654,00$ & $6.204 .668,08$ & $6.115 .469,00$ & $6.603 .630,58$ & 6.716 .050 \\
Fisheries - & & & & & \\
Marine & & & & & \\
Fisheries & & & & & \\
\hline $\begin{array}{l}\text { Public } \\
\text { Waters - }\end{array}$ & $446.692,00$ & $473.134,00$ & $464.722,00$ & $467.821,22$ & 532.247 \\
Inland & & & & & \\
Openwater & & & & & \\
Fisheries & & & & & \\
\end{tabular}

\begin{tabular}{lrrrrr}
\hline Amount & $6.484 .346,00$ & $6.677 .802,08$ & $6.580 .191,00$ & $7.071 .451,80$ & $7.248 .297,34$
\end{tabular}

Source: Center for Data, Statistics and Information of the Ministry of Marine Affairs and Fisheries in 2018 (Kementerian Kelautan dan Perikanan, 2018)

The data above shows that capture fisheries production in Indonesia is experiencing development. It shows that the capture fisheries industry's potential as raw material for processed food is also huge. However, based on the research results on several coastal anglers, it can be seen that the potential of residents in processing fishery products is still low. This condition is partly due to the small number of villagers who work as entrepreneurs. One of the factors that cause people to do entrepreneurship, especially in this study, fishers generally think that doing business requires considerable capital. Also, they think they feel they do not have the unique ability to run a business and have a very high risk (Atika Sari, 2019).

In general, coastal communities still consume fish in the form of culinary products and not food processing technology products that can be sold. The general obstacle is the low level of public knowledge, especially in producing quality processed fishery products (Mardhia et al., 2020). Also, traditional processors generally do not meet proper sanitation standards, so contamination is prone to occur in the products produced. In developing the processed food industry made from marine fish, various activities are needed to foster an entrepreneurial spirit from the fishing community, especially in processing fishery products, given the lack of people who work as processors. The community empowerment model might provide knowledge about useful food production methods, sanitation procedures and regulations, and 
processed product standards. Training is also needed, among others, in the manufacture of processed fishery products (shredded fish, beef jerky, flavor powder, and smoked fish), packaging and other things. There is also a need for socialization and training on Good Food Production (CPPB) methods, standard sanitation procedures, regulations and laws related to quality and an introduction to Indonesian National Standards for processed fishery products (shredded fish, smoked fish processing, jerky, quality salted fish) and various processed foods as well as distribution, transportation, marketing, and various other things. To produce quality food products, this is influenced by the product formulation and other supporting factors such as buildings, workers, management, facilities, water, etc., includes proper handwashing methods, cleaning and disinfection methods, pest control, packaging, types of fish, as raw materials, and others.

Individuals and business entities can carry out supplying processed food, one of which is Micro, Small and Medium Enterprises (MSMEs). Food Business Actors who produce food have a big responsibility because food is closely related to various human life sectors, including health, politic, economy, security and defense. One of the most critical impacts is the impact on safety and health for the community. Food safety and environmental concerns became a significant issue, especially in developing countries (Sulaiman et al., 2019). Food Safety is a condition and effort needed to prevent Food from the possibility of contamination of biological, chemical, and other objects that can disturb, harm and endanger human health and does not conflict with religion, belief, and community culture so that it is safe for consumption (Article 1 Number 5 Food Law).

Food is increasingly diverse; various processed and non-processed foods are increasingly circulating in the community. Processed foods are served in various ways that are increasingly attractive to consumers. On the other hand, various problems related to food are also occurring more and more, including in the procurement of raw materials, production processes, packaging, transportation, distribution, marketing to consumer use.

The broad diversity of endemic fish is an opportunity to be utilized optimally to open business opportunities in this sector. Therefore, fish handling and processing need to be pursued optimally because the handling and processing technology is quite simple and does not require large capital and sophisticated equipment. If the technology for handling and processing fish can be developed and implemented correctly, then the community's economy's added value can be achieved. This type of fish will be more economically valuable after receiving further treatment (Hadi, 2019).

The development of the processed food industry made from marine fish is very important for improving the community's welfare, primarily for anglers and the fishery industry's development. Fisheries are all activities related to the management and utilization of fish resources and their environment starting from pre-production, 
production, processing to marketing, which are carried out in a fishery business system (Article 1 number 1 of Law Number 31 of 2004 as amended by Law Number 45 of 2009).

The development of the processed food industry made from marine fish as one of the activities that can be carried out in the development of the fishery industry requires various parties, including the government, the private sector, and the community. Anglers have a strategic and decisive role in providing fish as a raw material in the food processing industry. However, it cannot be denied that Indonesia, which has such a massive marine resource potential, is often inversely proportional to the living conditions of fishers living in coastal communities. Therefore, efforts to develop the processed food industry made from marine fish have a significant relationship in improving the welfare of fishers in particular and the management of coastal areas in general.

According to Firth in Satria (Satria, 2015), fishing communities have similarities with farming communities. Their businesses' nature is small-scale with simple equipment and market organization, exploitation which is often related to cooperation problems, most of which rely on subsistence production and vary in level and economic behavior. These fishing communities generally live in coastal areas.

The management of coastal areas, which is one of the efforts to reduce poverty for coastal communities, has received significant attention, manifested in Law no. 27 of 2007 concerning the Management of Coastal Areas and Small Islands as amended by Law No. 1 of 2014. Empowerment of coastal communities is needed to give strength to groups of people deemed not to have the necessary strength for their progress, including fishermen groups (Soemarmi \& Diamantina, 2019).

Community empowerment to fishermen can be done in several ways. First is persuasive in the form of coaching. Coaching activities are an effort to increase fishermen's understanding and awareness of the messages being conveyed. Second is education carried out in the form of training. Through training, the skills of fishermen as the targeted group are expected to be improved. The training activities that have been carried out include increasing the understanding and skills of the targeted group in fisheries, especially related to fish as raw material for processed food. The capacitybuilding training in group management includes administration, financial management, management, and program implementation rules. Lastly is facilitating carried out in the form of providing business assistance, which is an effort to increase the participation of fishing communities. This business assistance can be provided directly or indirectly, both catching fish in the sea and processing the fish into processed food.

Through efforts to empower fishers, it is hoped that they will have more skills in various fields related to the management of marine fish as raw material for processed 
food to improve fishermen's welfare, development of coastal communities, and increase food security in coastal areas in particular and Indonesia in general.

\section{Business Partnership as an Alternative Model for Fishermen Empowerment in the Development of the Processed Food Industry}

Humans as social creatures and economic creatures need cooperation to get the maximum benefit. Partnerships can be an alternative effort to mobilize economic potential. A partnership is a relationship between economic actors based on mutually beneficial business ties and a synergistic working relationship. The Indonesian government has implemented business partnerships in small business development as regulated in Government Regulation no. 44 of 1997 concerning Partnerships. The Government Regulation on Partnership further regulates business partnership patterns regulated in the Law on Small Business, including the business climate, fostering and development, financing, and guarantees and partnerships. Regarding this partnership, PP No. 44 of 1997 has been revoked and declared invalid by PP No. 17 of 2013.

Article 25 (1) of Law Number 20 of 2008 concerning Micro, Small, and Medium Enterprises states that the Government, Local Government, Business, and the community facilitate, support and stimulate partnership activities that need, trust, consolidate, and benefit each other. Its paragraph (2) stipulates that the Partnership between Micro, Small and Medium Enterprises and the Partnership between Micro, Small and Medium Enterprises and Large Enterprises shall include skill transfer process in the fields of production and processing, marketing, capitals, human sources, and technology. Article 10 of Government Regulation No.17 of 2013 concerning Implementation of Law Number 20 of 2008 concerning Micro, Small, and Medium Enterprises, regulates the implementation of partnerships which must pay attention to the principles of partnership and uphold the business ethics. The partnership principle includes the principles of mutual need, mutual trust, mutual consolidation, and mutual benefit.

According to Article 26 of Law Number 20 of 2008 concerning Micro, Small and Medium Enterprises and PP. 17 of 2013, a partnership can be implemented with a nucleus-plasma pattern, subcontracting, franchising, general trading, distribution, and agency; as well as other forms of partnerships, such as profit sharing, operational cooperation, joint ventures, and outsourcing. The implementation of this partnership includes transferring skills in production and processing, marketing, capital, human resources, and technology by the Partnership pattern. In its implementation, large enterprises are prohibited from owning and controlling micro, small, and mediumsized businesses of their business partners as well as medium enterprises (Articles 11 and 12 of Government Regulation No.17 of 2013 concerning Implementation of Law Number 20 of 2008 about Micro, Small, and Medium Enterprises). The legal relationship between the parties in the business partnership is based on an agreement made in writing as stipulated in Article 29 of Government Regulation No. 
17 of 2013 concerning Implementation of Law Number 20 of 2008 concerning Micro, Small, and Medium Enterprises, PP No. 17 the Year 2013 concerning Implementation of Law Number 20 of 2008 concerning Micro, Small, and Medium Enterprises. Every form of partnership made by Micro, Small, and Medium Enterprises is outlined in a written partnership agreement in Indonesian. If one of the parties to the partnership agreement is a foreign person or legal entity, the partnership agreement must be made in Indonesian and foreign languages. The contents of the partnership agreement at least contain business activities, rights, and obligations of each party, a form of development and timeframe, as well as dispute resolution. Available sources of agreement law in Indonesia are in book III of the Civil Code (KUH Perdata).

Partnership as a model of cooperation can be a suitable alternative in empowering fishers to develop their potential as one of the parties in the development chain of the processed food industry made from marine fish. The Partnership Cooperation Model is an alternative for fishermen to develop the potential of the fishing industry, which has been done independently so far. The partnership cooperation model is based on a partnership agreement. The partnership agreement places fishermen as a strong party with the same power as other parties in the partnership agreement. Therefore, when the fishermen's position is equal to other parties, the fishermen can determine the selling price in the fishing industry. Partnership agreements are important to be carried out in Indonesia as an alternative for fishermen to develop the fishing industry that they have been doing, which is difficult to develop due to limited capital and limited access to finance faced by fishermen. Therefore, the Partnership Cooperation Model is very suitable to be applied in developing the fisheries industry in Indonesia.

\section{Conclusion}

The potential for the capture fisheries industry as raw material for processed food is also huge. However, based on the research results on several coastal anglers, it can be seen that the potential of residents in processing fishery products is still low. It is partly because few villagers work as entrepreneurs. One of the factors that cause people to do entrepreneurship, especially in this study, fishers generally think that doing business requires considerable capital. Also, they think they feel they do not have the unique ability to run a business and have a very high risk. Therefore, efforts to empower fishing communities to be more able to develop their potential in the processed food industry made from marine fish are very urgent to do.

The partnership cooperation model places the parties in an equal position. So that the parties in this case, including fishermen, have the same rights and obligations in the partnership agreement. Partnership agreements are beneficial for fishermen who face problems regarding limited capital and difficulties in marketing their catch. A partnership can be an appropriate alternative in empowering fishing communities. This business partnership is carried out based on a partnership agreement. 


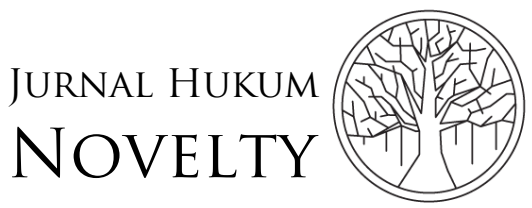

Volume 12, Issue 02, 2021, pp. 225-236

P-ISSN: 1412-6834

E-ISSN: 2550-0090

\section{Acknowledgment}

The authors would like to thank the Faculty of Law, Universitas Diponegoro, the Dean of the Faculty of Law, Universitas Diponegoro and the Institute for Research and Community Service at Universitas Diponegoro for the funds and resources provided to conduct this research. Sincere thanks are also extended to the anonymous reviewers and editors who provided constructive feedback so that this manuscript appears worthy of reading and citing.

\section{Declarations}

Author contribution : Author 1: initiated the research ideas, instrument construction, data collection, analysis, and draft writing; Author 2, Author 3, Author 4, and Author 5: revised the research ideas, literature review, data presentation and analysis, and the final draft.

Funding statement : The author states that the source of funding for this research comes from the Universitas Diponegoro Research Fund.

Conflict of interest $\quad$ : The authors declare no conflict of interest.

Additional information : No additional information is available for this paper.

\section{Reference}

Atika Sari, D. A. (2019). Integrasi Tata Kelola Kebijakan Pembangunan Kelautan Berkelanjutan. Jurnal Rechts Vinding: Media Pembinaan Hukum Nasional, 8(2), 147. https://doi.org/10.33331/rechtsvinding.v8i2.320

Badriyah, S. M., Mahmudah, S., \& Soemarmi, A. (2019). Leasing sebagai Alternatif Pembiayaan Kapal bagi Nelayan Kecil di Kota Pekalongan. Masalah-Masalah Hukum, 48(2), 204. https://doi.org/10.14710/mmh.48.2.2019.204-214

Badriyah, S. M., Mahmudah, S., Soemarmi, A., \& Kamello, T. (2019). Leasing Agreement on Financing SMEs in Fisheries Industry. Journal of Legal, Ethical and Regulatory Issues, 22(3), 1-7.

Burchi, F., \& De Muro, P. (2016). From food Availability to Nutritional Capabilities: Advancing Food Security Analysis. Food Policy, 60, 10-19. https://doi.org/10.1016/j.foodpol.2015.03.008

Denzin, N. K., \& Lincoln. Y. S. (1994). Introduction: Entering the Field of Qualitative Research. Sage Publication.

Diantha, I. M. P. (2017). Metodelogi Penelitian Hukum Normatif dalam Justifikasi Teori Hukum. Prenada Media Group.

Hadi, D. (2019). Penganekaragaman Olahan Ikan untuk Mendongkrak Produksi Olahan Ikan. Kementerian Kelautan Dan Perikanan, Dinas Perikanan Kabupaten Kutai Barat. https://diskan.kutaibaratkab.go.id/penganekaragaman-olahan-ikanuntuk-mendongkrak-produksi-olahan-ikan/

Hovdenak, I. M., Stea, T. H., Twisk, J., Te Velde, S. J., Klepp, K. I., \& Bere, E. (2019). Tracking of Fruit, Vegetables and Unhealthy Snacks Consumption from Childhood to Adulthood (15 Year Period): Does Exposure to a Free School Fruit 
Programme Modify the Observed Tracking? The International Journal of Behavioral Nutrition and Physical Activity, 16(1), 22. https://doi.org/10.1186/s12966-019-0783-8

Kaur, A., Scarborough, P., \& Rayner, M. (2019). Regulating Health and Nutrition Claims in the UK using a Nutrient Profile Model: An Explorative Modelled Health Impact Assessment. International Journal of Behavioral Nutrition and Physical Activity, 16(1), 1-11. https://doi.org/10.1186/s12966-019-0778-5

Kementerian Kelautan dan Perikanan. (2018). Kelautan dan Perikanan Dalam Angka 2018. Pusat Data dan Statistik Kementerian Kelautan dan Perikanan.

Kementerian Perindustrian Indonesia. (2016, March). Industri Pangan Berbasis Perikanan jadi Prioritas. Kementerian Perindustrian Indonesia. https://kemenperin.go.id/artikel/14788/Industri-Pangan-Berbasis-

Perikanan-Jadi-Prioritas

Mahmudah, S., Badriyah, S. M., Turisno, B. E., \& Soemarmi, A. (2019). Strategi Pemberdayaan Masyarakat dalam Pengelolaan Hutan Mangrove. MasalahMasalah Hukum, 48(4), 393. https://doi.org/10.14710/mmh.48.4.2019.393401

Malau, M. T. (2014). Aspek Hukum Peraturan dan Kebijakan Pemerintah Indonesia Menghadapi Liberalisasi Ekonomi Regional: Masyarakat Ekonomi Asean 2015. Jurnal Rechts Vinding: Media Pembinaan Hukum Nasional, 3(2), 163. https://doi.org/10.33331/rechtsvinding.v3i2.38

Marcano-Olivier, M., Pearson, R., Ruparell, A., Horne, P. J., Viktor, S., \& Erjavec, M. (2019). A Low-Cost Behavioural Nudge and Choice Architecture Intervention Targeting School Lunches Increases Children's Consumption of Fruit: A Cluster Randomised Trial. International Journal of Behavioral Nutrition and Physical Activity, 16(1), 20. https://doi.org/10.1186/s12966-019-0773-x

Mardhia, D., Kautsari, N., Syaputra, L. I., Ramdhani, W., \& Rasiardhi, C. O. (2020). Penerapan Protokol Kesehatan dan Dampak Covid-19 Terhadap Harga Komoditas Perikanan dan Aktivitas Penangkapan. Indonesian Journal of Applied Science and Technology, 1(2), 80-87.

Menski, W. (2006). Comparative Law in A Global Context, The Legal Systems of Asia and Africa (2nd ed.). Cambridge University Press.

Nur, M. (2021). Slavery of Indonesian Migrant Fishers: A Review of Regulation and Its Implementation. Yustisia Jurnal Hukum, 10(2), 145. https://doi.org/10.20961/yustisia.v10i2.53715

Robson, S. M., Ziegler, M. L., McCullough, M. B., Stough, C. O., Zion, C., Simon, S. L., Ittenbach, R. F., \& Stark, L. J. (2019). Changes in Diet Quality and Home Food Environment in Preschool Children Following Weight Management. International Journal of Behavioral Nutrition and Physical Activity, 16(1), 16. https://doi.org/10.1186/s12966-019-0777-6

Sanjeevi, N., Lipsky, L., Liu, A., \& Nansel, T. (2019). Differential Reporting of Fruit and Vegetable Intake Among Youth in A Randomized Controlled Trial of A Behavioral Nutrition Intervention. International Journal of Behavioral Nutrition and Physical 
Activity, 16(1), 1-8. https://doi.org/10.1186/s12966-019-0774-9

Satria, A. (2015). Pengantar Sosiologi Masyarakat Pesisir. Pustaka Obor.

Soemarmi, A., \& Diamantina, A. (2019). Konsep Negara Kepulauan dalam Upaya Perlindungan Wilayah Pengelolaan Perikanan Indonesia. Masalah-Masalah Hukum, 48(3), 241. https://doi.org/10.14710/mmh.48.3.2019.241-248

Strauss, A., Corbin, J., \& Busir. (1990). Qualitative Research; Grounded Theory Procedure and Techniques,. Sage Publication.

Sulaiman, N. S., Rovina, K., \& Joseph, V. M. (2019). Classification, Extraction and Current Analytical Approaches for Detection of Pesticides in Various Food Products. Journal of Consumer Protection and Food Safety, 14(3), 209-221. https://doi.org/10.1007/s00003-019-01242-4 